\title{
Effects of Superheat and Solute Additions on the Grain Size in Binary Copper Alloys
}

\author{
M. J. Balart ${ }^{1}$ - F. Gao ${ }^{1} \cdot$ J. B. Patel ${ }^{1} \cdot$ F. Miani ${ }^{2}$
}

Received: 21 September 2018 / Revised: 26 May 2019 / Accepted: 16 July 2019 / Published online: 7 August 2019

(c) The Author(s) 2019

\begin{abstract}
By utilizing data from the literature, we examine the effects of superheat and solute additions on the grain size (as measured by columnar grain length) in binary copper alloys. Our investigation provides support for an Arrhenius-like behavior of the superheat on the grain size. We also find a correlation between the columnar grain length at a constant degree of superheat and the variation of the reciprocal of the true growth restriction factor $(1 / Q)$ with $\mathrm{P}, \mathrm{Mg}, \mathrm{Mn}, \mathrm{Pb}$, and $\mathrm{Sn}$ solute additions to be a power of law of $1 / 3$, which gave a better fit than a linear one.
\end{abstract}

Keywords Grain size $\cdot$ Growth restriction $\cdot$ Solidification $\cdot$ Copper alloys

\section{Introduction}

Grain refinement of copper and copper alloys has recently attracted the interest of the scientific community [1-7]. It is worthwhile briefly highlighting previous studies on grain refinement in copper and copper alloys [8-13]: in air, in the late 1930s by Northcott [8, 9], and in a protective atmosphere of pure $\operatorname{Ar}$ ( $99.997 \mathrm{pct}$ ), in the early 1990s by Bustos and Reif [10-13].

Potent, efficient, and sufficient number of highly dispersed particles of a required size distribution and composition during solidification at large undercoolings are necessary conditions but not sufficient, as solute is also needed in the melt to restrict grain growth [14].

Since Easton and StJohn [15] first proposed the concept of thermodynamically determined $Q$ from the initial slope

M. J. Balart

maria.balart@brunel.ac.uk

F. Gao

feng.gao@brunel.ac.uk

J. B. Patel

jayesh.patel@brunel.ac.uk

F. Miani

fabio.miani@uniud.it

1 BCAST, Brunel University London, Uxbridge, Middlesex UB8 3PH, UK

2 University of Udine, Via delle Scienze 208, 33100 Udine, Italy in the constitutional supercooling, it has been adapted by several researchers [16-18]. Quested et al. [16] calculated $Q$ values in the $\mathrm{L}+\alpha$ region for some hypothetical ternary Al-X1-X2 systems. Schmid-Fetzer and Kozlov [17] evaluated $Q$ in multicomponent alloys.

$Q_{\text {true }}=\left(\frac{\partial\left(\Delta T_{\mathrm{cs}}\right)}{\partial f_{\mathrm{s}}}\right)_{f_{\mathrm{s}} \rightarrow 0}$

where $\Delta T_{\mathrm{cs}}$ is the constitutional undercooling and $f_{\mathrm{s}}$ is the solid fraction.

$Q$ reflects the phase diagram of the alloy system and has a relationship with grain size [17], which was empirically found in some cases to be linear, as illustrated with some examples from the literature for $\mathrm{Mg}[19,20]$ and $\mathrm{Al}[21]$ alloys in Ref. [22], where $Q$ values were calculated from the conventional relationship:

$Q_{\text {conv. }}=m c_{0}(k-1)$

where $m$ is the slope of the liquidus, $c_{0}$ is the solute concentration, and $k$ is the equilibrium distribution coefficient [5].

In the aforementioned study, Men and Fan [22] developed an analytical model for determining the effects of different solute additions on grain refinement under isothermal solidification. The grain size was found to be directly related to $\left(1 / Q_{\text {conv. }}\right)^{1 / 3}$ through a parameter $B$, which is dependent on the diffusion coefficient of the solute in the liquid phase, undercooling, growth velocity, and solid fraction at the moment of recalescence-in that solute enrichment at the solid/liquid 
interface can reduce the growth velocity and can increase the maximum undercooling before recalescence.

$d=B\left(\frac{1}{Q_{\text {conv. }}}\right)^{1 / 3}$

where $B$ is a constant independent of alloy composition. Equation 3 gave a better fit to the experimental data than a linear one for binary $\mathrm{Al}-\mathrm{Zn}$ and $\mathrm{Al}-\mathrm{Si}$ alloys as well as Al-based wrought alloys solidified under TP-1 casting conditions [22].

We have found it of interest to explore the efficacy of the $1 / 3$ power law (Eq 3 ), but from the true growth restriction factor framework, in binary copper alloys. By using experimental data from Northcott's work [9], the effect of solute additions on the grain size has been evaluated in binary copper alloys using the analytical model provided by Men and Fan [22] for constant and various degrees of superheat. Liquid superheat is one of the main factors controlling heat transfer phenomena and solidification in upcasting of copper and brass and hence fundamental to understanding and predicting heat extraction rates [23]. The true growth restriction factor $Q_{\text {true }}$ has been calculated rigorously for binary $\mathrm{Cu}-\mathrm{X}$ alloys, where $\mathrm{X}=\mathrm{Al}$, $\mathrm{Zn}, \mathrm{P}, \mathrm{Mg}, \mathrm{Mn}, \mathrm{Ni}, \mathrm{Pb}$, and $\mathrm{Sn}$.

\section{Thermodynamically Determined Q}

$Q_{\text {true }}$ was thermodynamically calculated for each amount of solute present in binary copper alloys using the methodology described by Cziegler and Schumacher [3] based on the procedure given by Schmid-Fetzer and Kozlov [17] as follows. The development of the solid fraction $\left(f_{s}\right)$ was calculated using the Scheil-Gulliver solidification equation generally for a temperature step of $0.01{ }^{\circ} \mathrm{C}$, unless otherwise stated in Table 1 . Software package Pandat (version 8.0) and the thermodynamic databases available in the literature [24-30] were used to calculate cooling.

$\Delta T_{c s}=T_{L}-T$

where $T_{\mathrm{L}}$ is the liquidus temperature.

$\Delta T_{c s}=a+b f_{s}+c f_{s}^{2}$

The derivative of the second-order polynomial at $f_{\mathrm{s}} \rightarrow 0$ leads to $Q_{\text {true }}=b$

It is of interest to note that, in the limit $f_{\mathrm{s}} \rightarrow 0$, the true and conventional growth restriction factors are identical (see the derivation in Ref. [17]).

$Q_{\text {true }}=\left(\frac{\partial\left(\Delta T_{\mathrm{cs}}\right)}{\partial f_{\mathrm{s}}}\right)_{f_{\mathrm{s}} \rightarrow 0}=m c_{0}(k-1)=Q_{\text {conv. }}$

In this work, $Q$ refers to $Q_{\text {true }}$.

\section{Results and Discussion}

\section{Superheat Effect}

The effect of both cast at $1200{ }^{\circ} \mathrm{C}$ and at a constant superheat of $100{ }^{\circ} \mathrm{C}$ on the grain size (as measured by columnar grain length) in binary $\mathrm{Cu}-X \mathrm{Al}$ alloys of Ref. 9, where $X=0.1-7$ wt. \%, is shown in Fig. 1a, from which it can be seen that the grain structure of the binary $\mathrm{Cu}-\mathrm{Al}$ system is representative of a type of an unrestricted columnar grain growth $(101.6 \mathrm{~mm})$ due to a high thermal gradient from liquid to solid at $1 / Q \geq 10(1 / K)$. This behavior is reflected in a low correlation coefficient of the 1/3 power law of Eq 3 (Fig. 1a). These results were confirmed again by an addition of $0.21 \%$ of $\mathrm{Al}-5 \mathrm{Ti}-1 \mathrm{~B}$ grain refiner to deoxidized copper, cast at $1150{ }^{\circ} \mathrm{C}$ under TP- 1 casting conditions-constant cooling rate of $3.5 \mathrm{~K} / \mathrm{s}$ at the center of a cross section located $38 \mathrm{~mm}$ from the base of the TP- 1 sample-as described in Ref. [5]. As a result, excessive coarsening occurred as shown in Fig. 1b.

Again, it is also worthwhile reiterating the earlier point on the effect of solidification conditions on the grain size. Therefore, in theory, when comparing grain sizes from different alloys, those should have been cast at the same degree of superheat. However, in practice, this is not always the case, as generally reported in the literature [31]. Bolzoni and Babu [31] investigated superheat effects in binary $\mathrm{Al}-X \mathrm{Si}$ alloys, where $X=4-10 \mathrm{wt} . \%$, while fitting the experimental data to the Arrhenius-like relation (Eqs 7-8) that associated the grain size variation $(\Delta d)$ to the inverse of the difference between superheat $(\Delta T)$ because solidification is a diffusive process.

$\Delta d=A e^{-\frac{E_{\mathrm{a}}}{R \Delta T}}$

where $\Delta d$ is the corresponding change in the difference in grain size from an alloy cast at a constant temperature compared with that cast from a constant superheat; $A$ is the pre-exponential constant; $E_{\mathrm{a}}$ is the activation energy; and $R$ is the gas constant $8.3145 \mathrm{~J} / \mathrm{mol} \mathrm{K}$.

$\ln (\Delta d)=\ln A-\frac{E_{\mathrm{a}}}{R \Delta T}$

The positive effect of decreasing the casting temperature (superheat) on grain size at two cooling rate conditions was highlighted in Ref. [10]. Northcott also observed this trend in his study [8] and reported that the average length of columnar grains decreased, from 20.32 to $12.7 \mathrm{~mm}$ for a binary $\mathrm{Cu}-0.5 \mathrm{Sn}$ alloy (in wt.\%), on decreasing the superheat from 200 to $100{ }^{\circ} \mathrm{C}$, and from 20.32 to $10.16 \mathrm{~mm}$ for a binary $\mathrm{Cu}-1 \mathrm{Ca}$ alloy (in wt.\%), on decreasing the superheat from 140 to $10{ }^{\circ} \mathrm{C}$. From Fig. 1a, the length of columnar grains decreased from 37.59 to $25.4 \mathrm{~mm}$ for $\mathrm{Cu}-5 \mathrm{Al}$ alloy $(1 / Q=0.281 / K)$ and from 60.96 to $34.54 \mathrm{~mm}$ for $\mathrm{Cu}-7 \mathrm{Al}$ 


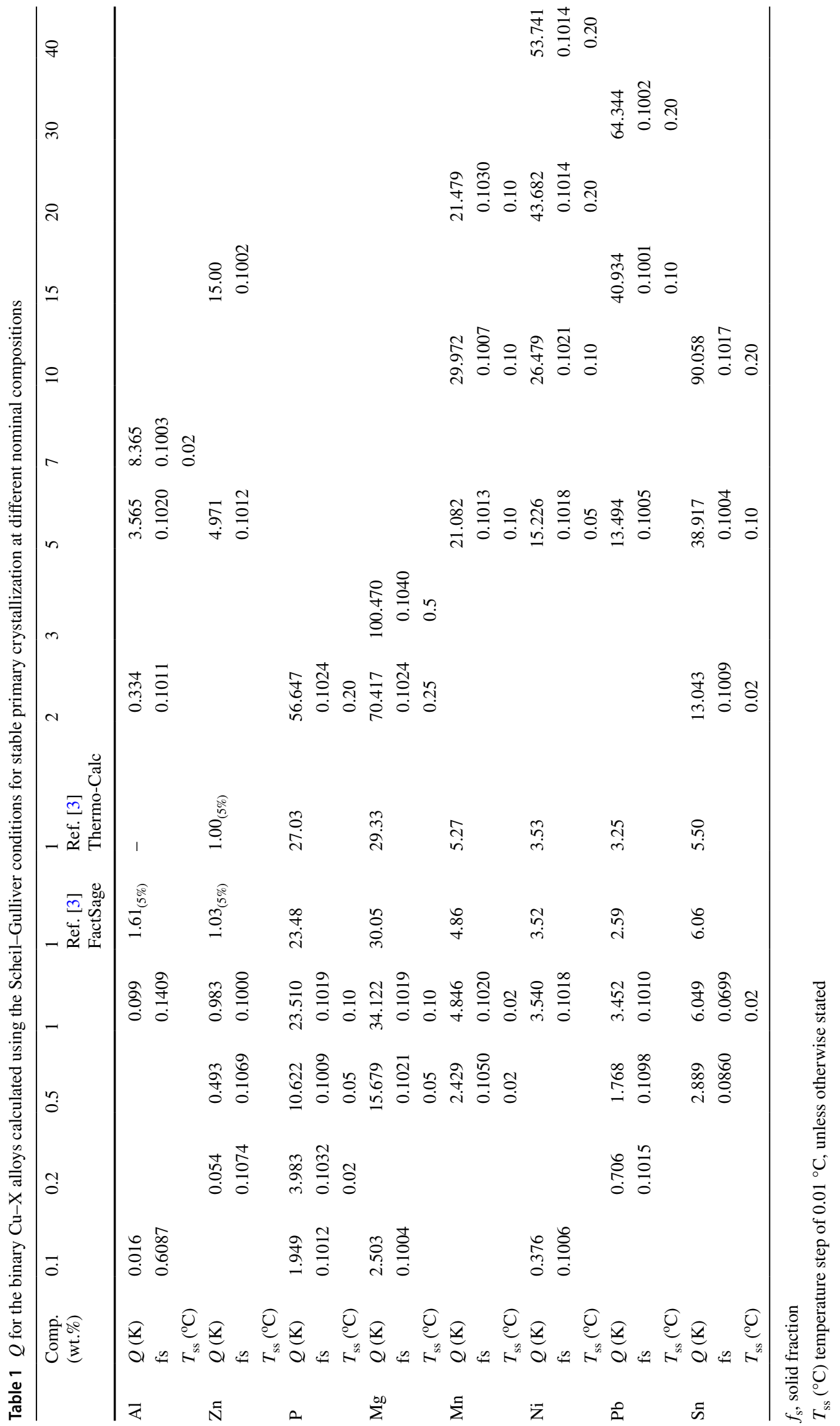




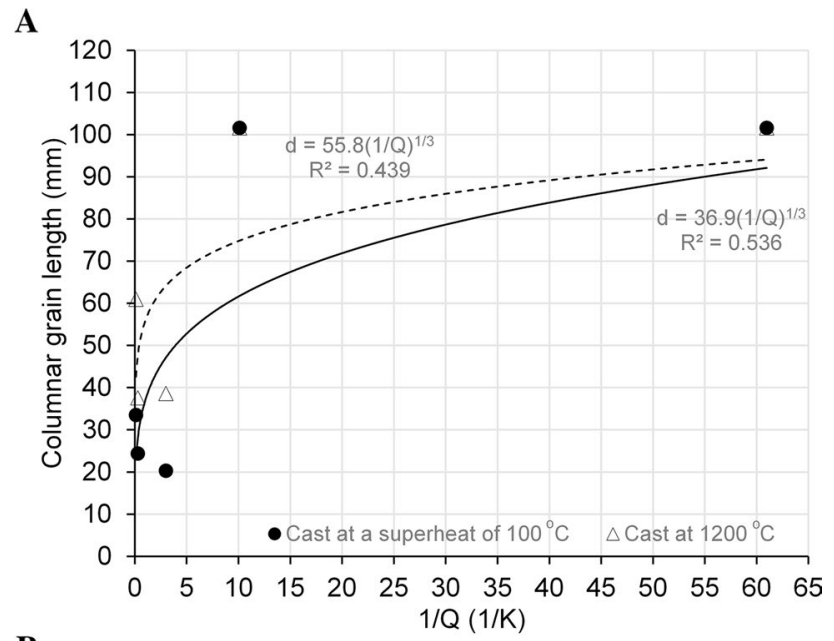

B

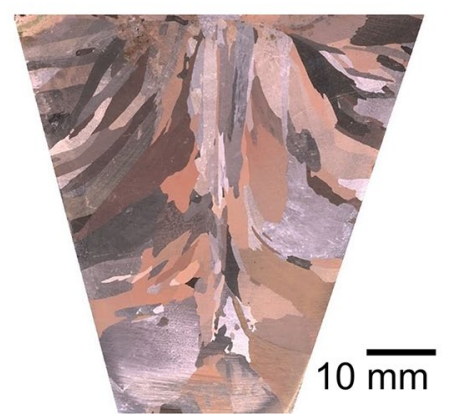

Fig. 1 (a) Variation of the average columnar grain length values [9] with growth restriction factor $Q$ for $\mathrm{Cu}-X \mathrm{Al}$, where $X=0.1-7$ wt.\% and (b) macrograph of copper with an addition of $0.21 \%$ of $\mathrm{Al}-5 \mathrm{Ti}-$ 1B grain refiner, cast at $1150{ }^{\circ} \mathrm{C}$

alloy $(1 / Q=0.121 / \mathrm{K})$, when cast at $1200{ }^{\circ} \mathrm{C}$ to cast at a constant superheat of $100{ }^{\circ} \mathrm{C}$, respectively. The $A$ value obtained from Eq 8 is 89.56 , and the $E_{\mathrm{a}}$ value is $474.7 \mathrm{~J} / \mathrm{mol}$.

\section{Solutal Effect}

$Q$ values obtained in the present investigation are given in Table 1 as well as those of Ref. [3] obtained for a constant solute addition of $1 \%$ of $\mathrm{Al}, \mathrm{Zn}, \mathrm{P}, \mathrm{Mg}, \mathrm{Mn}, \mathrm{Ni}, \mathrm{Pb}$, and $\mathrm{Sn}$. From Table 1, it can be seen that similar $Q$ values at $1 \%$ of solute addition were obtained when comparing FactSage and Thermo-Calc databases with those of this study. Columnar grain length values of Ref. [9] which were determined for additions into copper rapidly cast in air $(\sim 3.175 \mathrm{~kg}$ ingot castings, $76.2 \mathrm{~mm}$ diameter and $\sim 76.2 \mathrm{~mm}$ height) are plotted against the corresponding calculated $1 / Q$ values using Eq 3 in Figs. 1a , 2, 3, 4, 5, 6, 7, and 8. The results were fitted to the $1 / 3$ power law Eq 3 . It can be seen that the $1 / 3$ power law model can generally explain the experimental data for casts at a constant superheat.

$\mathrm{Zn}$ has a rather high equilibrium vapor pressure which can be found in thermodynamic tables $[32,33]$. As a result,

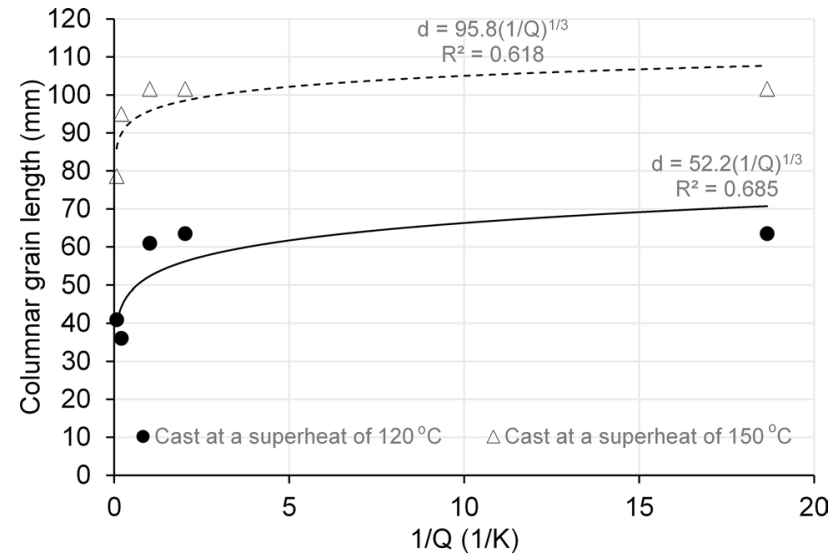

Fig. 2 Variation of the average columnar grain length values [9] with growth restriction factor $Q$ for $\mathrm{Cu}-X \mathrm{Zn}$, where $X=0.2-15$ wt.\%

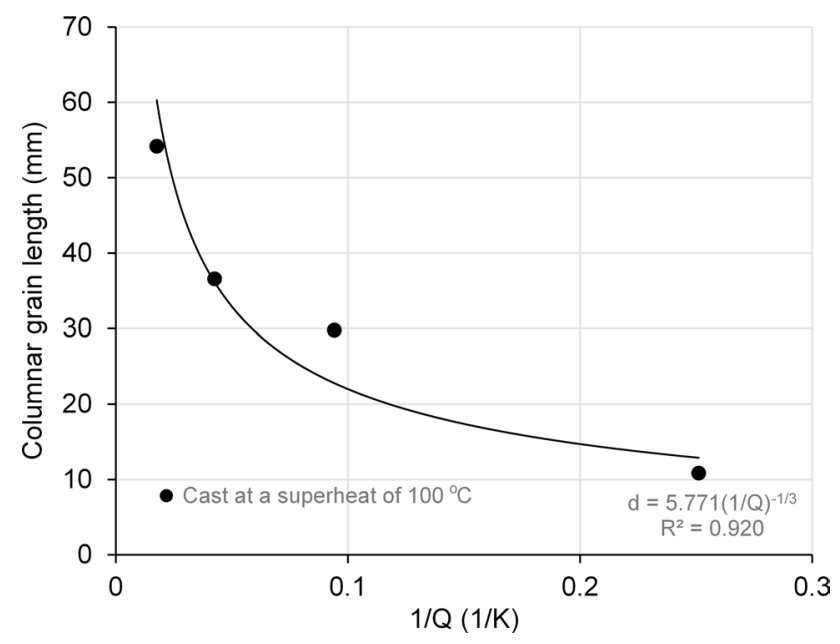

Fig. 3 Variation of the average columnar grain length values [9] with growth restriction factor $Q$ for $\mathrm{Cu}-X \mathrm{P}$, where $X=0.1-2$ wt.\%

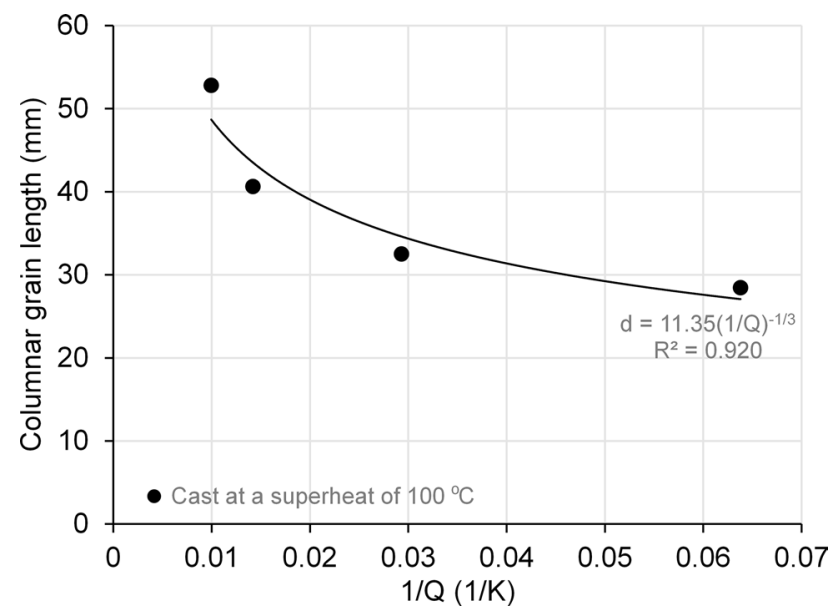

Fig. 4 Variation of the average columnar grain length values [9] with growth restriction factor $Q$ for $\mathrm{Cu}-X \mathrm{Mg}$, where $X=0.1-3 \mathrm{wt} . \%$ 


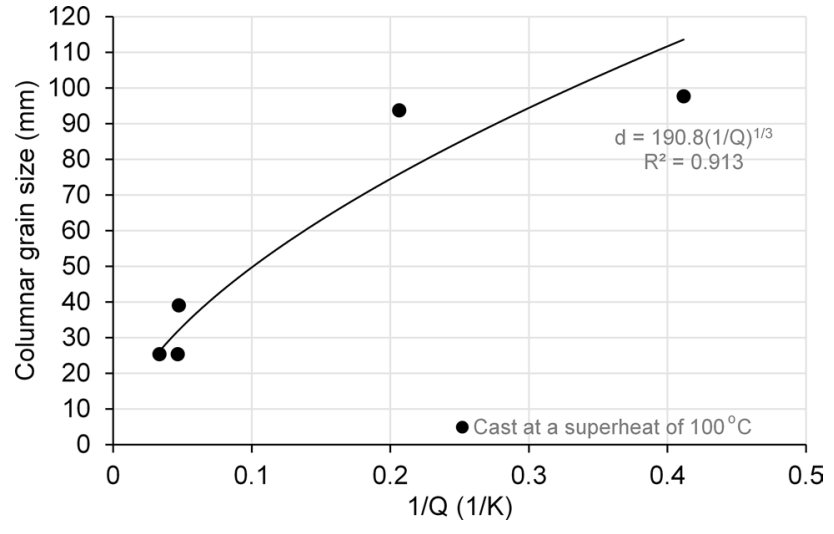

Fig. 5 Variation of the average columnar grain length values [9] with growth restriction factor $Q$ for $\mathrm{Cu}-X \mathrm{Mn}$, where $X=0.5-20 \mathrm{wt} . \%$

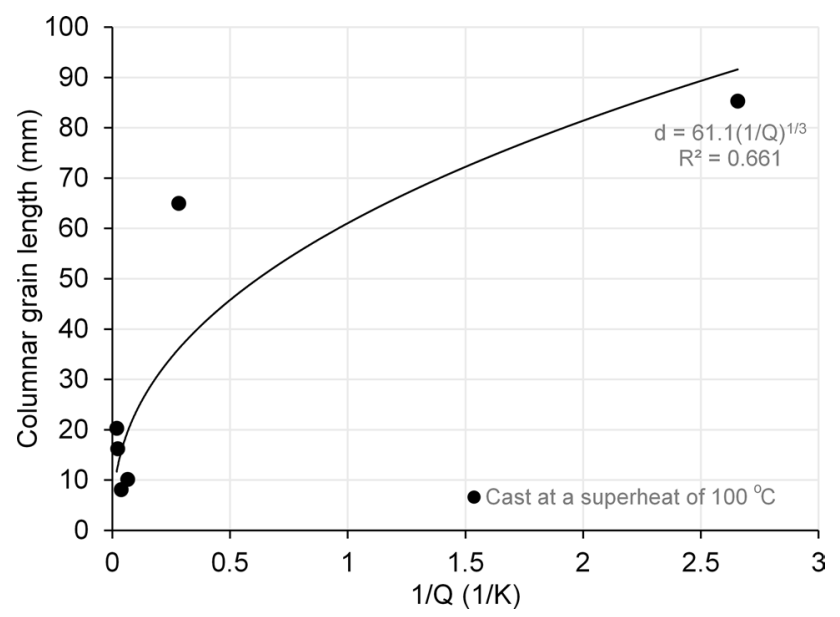

Fig. 6 Variation of the average columnar grain length values [9] with growth restriction factor $Q$ for $\mathrm{Cu}-X \mathrm{Ni}$, where $X=0.1-40 \mathrm{wt}$.\%

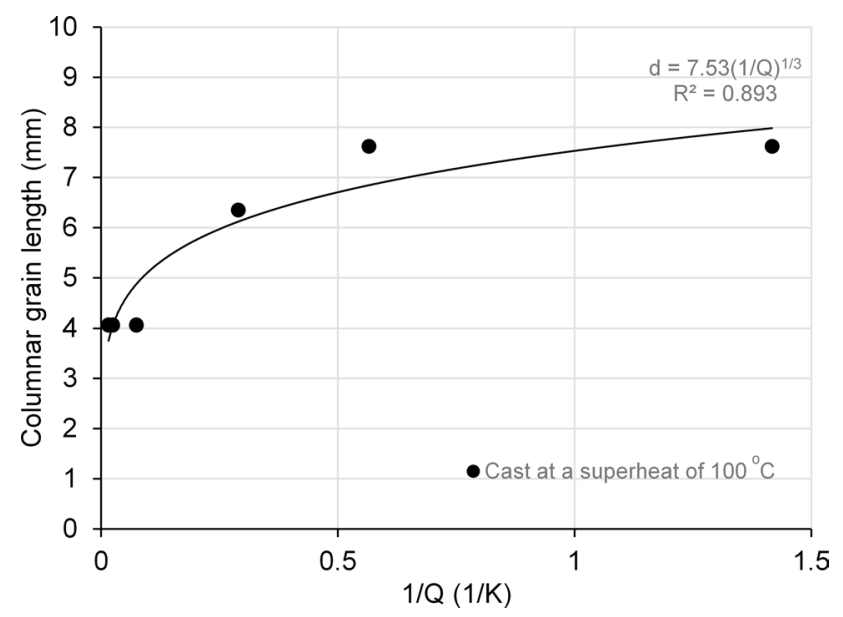

Fig. 7 Variation of the average columnar grain length values [9] with growth restriction factor $Q$ for $\mathrm{Cu}-\mathrm{XPb}$, where $X=0.2-30 \mathrm{wt}$.\%

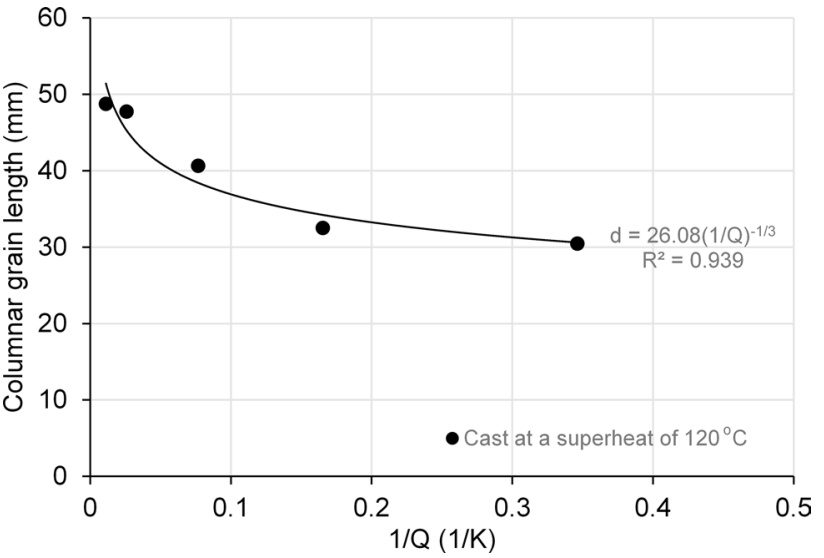

Fig. 8 Variation of the average columnar grain length values [9] with growth restriction factor $Q$ for $\mathrm{Cu}-X \mathrm{Sn}$, where $X=0.5-10 \mathrm{wt} . \%$

these $\mathrm{Cu}-\mathrm{Zn}$ alloys would be expected to have a lower $\mathrm{Zn}$ content in the base composition than its corresponding nominal composition, which in turn may have resulted in a lower correlation coefficient of the 1/3 power law of Eq 3 (Fig. 2) compared with those of Figs. 3, 4, 5, 7, and 8. Those examples illustrate the need for consistency when comparing not only the superheat effect but also the solutal effect on the grain size of in copper alloys.

All that brings back to the point that both nucleating particles and solute additions are needed for effective grain refinement. This situation is qualitatively exemplified in Fig. 9, which shows (in wt.\%) that $0.4 \mathrm{Zr} ; 0.4 \mathrm{Zr}-0.15 \mathrm{P}$; and $0.4 \mathrm{Zr}-0.015 \mathrm{Ag}$ alloys had a columnar grain structure, whereas $0.4 \mathrm{Zr}-0.04 \mathrm{P}$ and $0.4 \mathrm{Zr}-0.04 \mathrm{P}-0.015 \mathrm{Ag}$ alloys gave columnar-to-equiaxed transition (CET). The reason for variation in grain structure was ascribed to be due to the ease of nucleation [5] rather than only the effect of $\mathrm{Zr}$ additions of $0.4 \%$.

\section{Conclusions}

This study has examined the effect of superheat and solute additions on the grain size (as measured by columnar grain length) in copper alloys by utilizing data from the literature and by thermodynamically calculating the growth restriction factor for each amount of solute present in binary copper alloys.

An Arrhenius-like behavior has been exemplified for the corresponding change in the difference in grain size (columnar grain length) for solute additions of $\mathrm{Cu}-5 \mathrm{Al}$ and $\mathrm{Cu}-7 \mathrm{Al}$ (in wt.\%) cast at $1200{ }^{\circ} \mathrm{C}$ compared with that cast from a constant superheat of $100{ }^{\circ} \mathrm{C}$. It has also been found a correlation between the columnar grain length at a constant degree of superheat and the variation of the 
Fig. 9 Macrographs of $\mathrm{Cu}-0.4 \mathrm{Zr}, \mathrm{Cu}-0.4 \mathrm{Zr}-0.15 \mathrm{P}$, $\mathrm{Cu}-0.4 \mathrm{Zr}-0.015 \mathrm{Ag}$, and $\mathrm{Cu}-$ $0.4 \mathrm{Zr}-0.04 \mathrm{P}-0.015 \mathrm{Ag}$ alloys (in wt.\%). Chemical compositions by ICP-OES (in wt ppm) and casting temperatures are shown for each TP-1 sample [5]
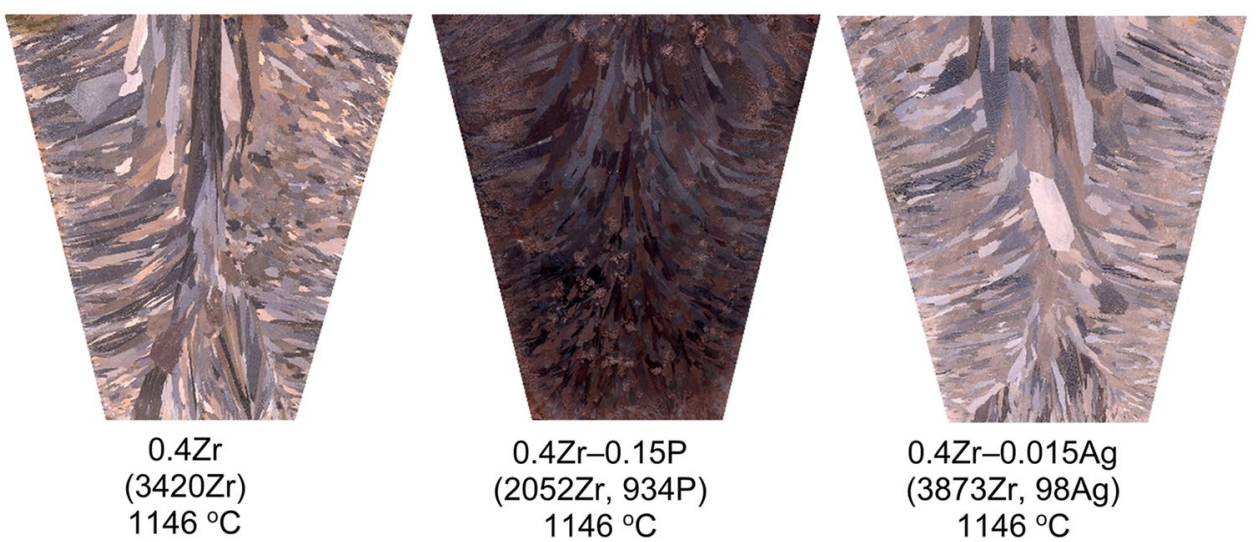
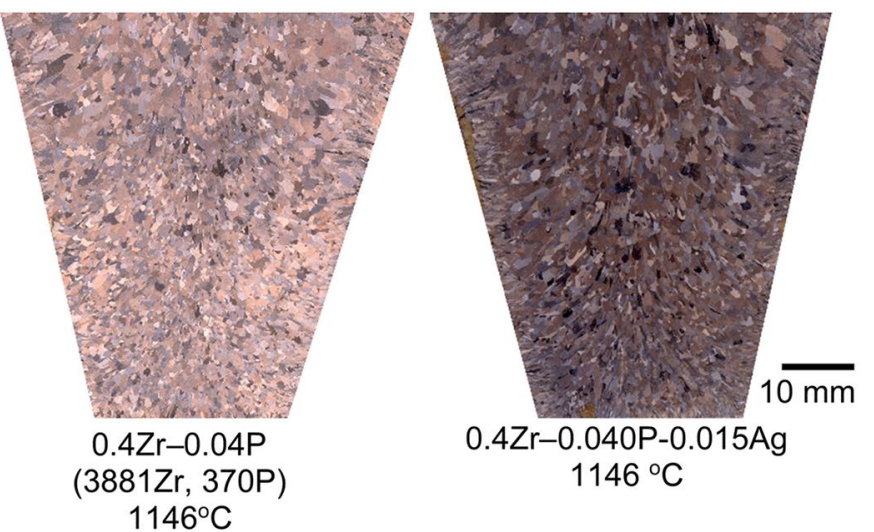

reciprocal of the true growth restriction factor $(1 / Q)$ with $\mathrm{P}, \mathrm{Mg}, \mathrm{Mn}, \mathrm{Pb}$, and $\mathrm{Sn}$ solute additions to be a power of law of $1 / 3$, which gave a better fit than a linear one.

Acknowledgments The support of the EPSRC (UK) is gratefully acknowledged.

Open Access This article is distributed under the terms of the Creative Commons Attribution 4.0 International License (http://creativeco mmons.org/licenses/by/4.0/), which permits unrestricted use, distribution, and reproduction in any medium, provided you give appropriate credit to the original author(s) and the source, provide a link to the Creative Commons license, and indicate if changes were made.

\section{References}

1. J.M. Rojas Arango, T.P. Nagasima, M. Aquino Martorano, A. Fernando Padiha, Inoculação de bronzes a partir de adições de zircônio, in Contribuição técnica ao $71^{\circ}$ Congresso Annual da ABM - Internacional e ao $16^{\circ}$ ENEMET - Encontro Nacional de Estudiantes de Engenharia Metalúrgica, de Materiais e de Minas. Parte integrante da ABM Week, realizada de 26 a 30 de Setembro de 2016, Rio de Janeiro, RJ, Brasil

2. A.K. Cziegler, P. Schumacher, Preliminary investigation of the grain refinement mechanism in $\mathrm{Cu}$ alloys, in Proceedings of the 6th Shape Cast Int Symp TMS, Feb 14-18, ed. by M. Tiryakioglu, M. Jolly, G. Byczynski (Wiley, Nashville, TN, 2016), p $159-166$
3. A.K. Cziegler, P. Schumacher, Investigation of the correlation between growth restriction and grain size in $\mathrm{Cu}$ alloys. Int. J. Cast Metals Res. 30(4), 251-255 (2017)

4. M.J. Balart, J.B. Patel, F. Gao, Z. Fan, Grain refinement of DHP copper by elemental additions. Int. J. Cast Metals Res. 28(4), 248-256 (2015)

5. M.J. Balart, J.B. Patel, F. Gao, Z. Fan, Grain refinement of deoxidized copper. Metall. Mater. Trans. A 47(10), 4988-5011 (2016)

6. O. Bustos, R. Mannheim, L. Cruz, Estudio de la combinación de los procesos de afinamiento de grano de colada y filtrado en latones. Rev. Metal. Madrid 35(4), 222-232 (1999)

7. A. Cziegler, O. Geraseva, P. Schumacher, Numerical and experimental investigation of the influence of growth restriction on grain size in binary $\mathrm{Cu}$ alloys. Metals 7, 383 (2017)

8. L. Northcott, The influence of alloying elements on the crystallization of copper. Part I. Small additions and the effect of atomic structure. J. Inst. Metals 62, 101-136 (1938)

9. L. Northcott, The influence of alloying elements on the crystallization of copper. Part II. Large additions and the part played by the constitution. J. Inst. Metals 65, 173-204 (1939)

10. O.L. Bustos, W. Reif, Kornfeinung von reinstkupfer durch chemische zusätze, teil 1. Metall 47(11), 1005-1014 (1993)

11. O.L. Bustos, W. Reif, Kornfeinung von reinstkupfer durch chemische zusätze, teil 2. Metall 48(2), 123-127 (1994)

12. O.L. Bustos, W. Reif, Kornfeinung von reinstkupfer durch chemische zusätze, teil 3. Metall 48(7), 538-548 (1994)

13. W. Reif, 75 Jahre Kornfeinung: Marschroute Spitzen-Technik. Metall 52(3), 120-130 (1998)

14. Z. Fan, An epitaxial model for heterogeneous nucleation on potent substrates. Metall. Mater. Trans. A 44A, 1409-14018 (2013) 
15. M.A. Easton, D.H. StJohn, A model of grain refinement incorporating the alloy constitution and potency of nucleation sites. Acta Mater. 49(10), 1867-1878 (2001)

16. T.E. Quested, A.T. Dinsdale, A.L. Greer, Thermodynamic modelling of growth restriction effects in aluminium alloys. Acta Mater. 53(5), 1323-1334 (2005)

17. R. Schmid-Fetzer, A. Kozlov, Thermodynamic aspects of grain growth restriction in multicomponenet alloy solidification. Acta Mater. 59(15), 6133-6144 (2011)

18. M. Qian, P. Cao, M.A. Easton, S.D. McDonald, D.H. StJohn, An analytical model for constitutional supercooling driven grain formation and grain size prediction. Acta Mater. 58(9), 3262-3270 (2010)

19. D.H. StJohn, M. Qian, M.A. Easton, P. Cao, Z. Hildebrand, Grain refinement of magnesium alloys. Metall. Mater. Trans. A 36A, 1669-1679 (2005)

20. Y.C. Lee, A.K. Dahle, D.H. StJohn, The role of solute on grain refinement of magnesium. Metall. Mater. Trans. A 31A, 28952906 (2000)

21. M.A. Easton, D.H. StJohn, An analysis of the relationship between grain size, solute content, and the potency and number density of nucleant particles. Metall. Mater. Trans. A 36A, 1911-1920 (2005)

22. H. Men, Z. Fan, Effect of solute content on grain refinement in an isothermal melt. Acta Mater. 59, 2704-2712 (2011)

23. K. Härkki, J. Miettinen, Mathematical modelling of copper and brass upcasting. Metall. Mater. Trans. B 30B, 75-98 (1999)

24. J. Miettinen, Thermodynamic description of $\mathrm{Cu}-\mathrm{Sn}-\mathrm{P}$ system in the copper-rich corner. Calphad 25(1), 67-78 (2001)

25. X.J. Liu, R. Kainuma, C.P. Wang, I. Ohnuma, K. Ishida, Experimental investigation and thermodynamic calculation of the phase equilibria in the $\mathrm{Cu}-\mathrm{Sn}$ and $\mathrm{Cu}-\mathrm{Sn}-\mathrm{Mn}$ systems. Metall. Mater. Trans. A 35(6), 1641-1654 (2004)
26. M. Jiang, C.P. Wang, X.J. Liu, I. Ohnuma, R. Kainuma, G.P. Vassilev, K. Ishida, Thermodynamic calculation of phase equilibria in the $\mathrm{Cu}-\mathrm{Ni}-\mathrm{Zn}$ system. J. Phys. Chem. Solids 66(2-4), 246-250 (2005)

27. J. Miettinen, Thermodynamic description of the $\mathrm{Cu}-\mathrm{Al}-\mathrm{Sn}$ system in the copper-rich corner. Metall. Mater. Trans. A 33(6), 1639$1648(2004)$

28. J. Vrešt'ál, J. Štepánková, B. Broz, Thermodynamics of the copper-manganese system. Knudsen-cell mass spectrometric study of the liquid $\mathrm{Cu}-\mathrm{Mn}$ system and calculation of the phase diagram. Scand. J. Metall. 25(5), 24-231 (1996)

29. T. Buhler, S.G. Fries, P.J. Spencer, H.L. Lukas, A thermodynamic assessment of the $\mathrm{Al}-\mathrm{Cu}-\mathrm{Mg}$ ternary system. J. Phase Equilib. 19(4), 317-333 (1998)

30. C.P. Wang, X.J. Liu, I. Ohnuma, R. Kainuma, K. Ishida, Thermodynamic assessment of the $\mathrm{Cu}-\mathrm{Ni}-\mathrm{Pb}$ system. Calphad 24(2), 149-167 (2000)

31. L. Bolzoni, N.H. Babu, Considerations on the effect of solutal on the grain size of castings from superheated melts. Mater. Lett. 201, 9-12 (2017)

32. O. Kubaschewski, C.B. Alcock, Metallurgical Thermochemistry, vol. 20, 5th edn. (Pergamon Press Ltd., Oxford, 1979), pp. $358-384$

33. T. Iida, R.I.L. Guthrie, The Physical Properties of Liquid Metals (Oxford University Press, New York, 1988), p. 88

Publisher's Note Springer Nature remains neutral with regard to jurisdictional claims in published maps and institutional affiliations. 